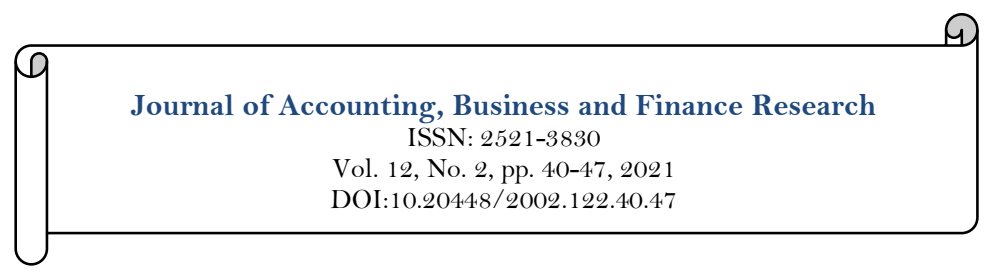

\title{
Corporate Tax and Firm Value Under M\&M Proposition II
}

\author{
Adolphus J. Toby ${ }^{1 *}$ \\ James A. Sarakiri ${ }^{2}$ \\ ${ }_{1,2}^{1,}$ Department of Banking and Finance, Rivers State University, Port Harcourt, Rivers State, Nigeria. \\ 'Email: toby.adolphus@ust.edu.ng.
}

\begin{tabular}{|c|c|}
\hline Abstract & \\
\hline $\begin{array}{l}\text { This study examines the effect of corporate tax on the market value } \\
\text { of firms within the framework of the modified Modigliani and Miller } \\
\text { (M\&M) work (Modigliani \& Miller, 1963). Using secondary annual } \\
\text { data of } 60 \text { Nigerian quoted companies carefully selected from all } \\
\text { sectors of the country's economy, we adopted the panel data } \\
\text { methodology to carry out an inferential statistical analysis with the } \\
\text { aid of the EViews package on the data covering the period from } 1990 \\
\text { to } 2016 \text {. Based on the adjusted R-squared, approximately } 60 \% \text { of the } \\
\text { total variation in the market value of firms is due to corporate tax. } \\
\text { The study also provides evidence that there is a highly significant } \\
\text { linear relationship between corporate tax and the market value of } \\
\text { firms as well as a strong feedback influence running from the market } \\
\text { value of firms to corporate tax. Overall, our findings agree with the } \\
\text { conclusion by Modigliani and Miller (1963) that the tax shields that } \\
\text { levered firms enjoy significantly enhance their market value. It is } \\
\text { also an indication that the Nigerian government is subsiding the cost }\end{array}$ & $\begin{array}{l}\text { Keywords: } \\
\text { Corporate tax } \\
\text { Market value of firms } \\
\text { Panel data. } \\
\text { Licensed: } \\
\text { This work is licensed under a } \\
\text { Creative Commons Attribution } 4.0 \\
\text { License. } \\
\text { Publisher: } \\
\text { Scientific Publishing Institute } \\
\text { Received: } 18 \text { May } 2021 \\
\text { Revised: } 21 \text { June } 2021 \\
\text { Accepted: } 16 \text { July } 2021 \\
\text { Published: } 5 \text { August } 2021 \\
\text { ( Corresponding Author) }\end{array}$ \\
\hline
\end{tabular}

Funding: This study received no specific financial support.

Competing Interests: The authors declare that they have no competing interests.

\section{Introduction}

One of the assumptions of the irrelevance hypothesis proposed by Modigliani and Miller (1958) is that firms are operating in a perfect world where there are no transaction costs, corporate tax and asymmetric information between managers and investors. In such a world, a firm can finance its assets or new projects with any combination of debt and equity without affecting its value. It therefore suggests that a firm's earning power and business risk are the only determining factors of its market value. This idea prompted consistent academic research which contributed significantly to the robustness of both theoretical and empirical finance literature. However, it has also generated some controversy in view of the initial position of the authors which seems to have no practical relevance.

The argument received considerable criticism for lacking practical relevance due to its restrictive assumptions, which are also acknowledged by the authors themselves. In the light of this, Modigliani and Miller (1963) modified their earlier model by including corporate tax which, according to them, has practical relevance. Because interest paid on long-term debt is tax deductible, it provides an incentive to use debt capital, and the more a firm uses debt, the more its profitability increases. A levered firm tends to be more profitable than an unlevered firm and this is reflected in the value of the firm. Thus, firms that are levered have higher market value than firms that use only equity.

Based on this development, and in response to the limitations of the irrelevance theory, several alternative theories explaining the relationship between capital structure and firm value have emerged from the literature. Among the competing theories are the pecking order theory and the trade-off theory. The pecking order 
theory holds that managers rank their capital sources in order of preference. The top preference is internal equity, which is the cheapest finance source over debt and new equity. However, they prefer debt over equity when there is a need for external financing. On the other hand, the trade-off theory holds that a firm's value is maximized at the point of balance between the tax benefit of debt and the associated bankruptcy costs. Thus, both theories predict that there is a significant relationship between the capital structure of a firm and its market value. However, while the pecking order theory predicts a negative relationship, the trade-off theory predicts a positive relationship (Akeem, 2014; Baker \& Wurgler, 2002; Campbell \& Kelly, 1994; Myers \& Majluf, 1984).

These theories, and other recent theories, including the agency theory and the market timing hypothesis, have been extensively empirically tested with a wide range of findings contributing to the literature on the effects of capital structure on the market value of firms. For instance, Miller (1977) and Myers (1984) maintain that the tax effect on firm value through debt financing is likely to be offset by other taxes, such as personal income tax and shareholder dividend tax. There are also other studies, such those by Bradley, Jarrell, and Kim (1984); Baskin (1989); Barclay and Smith (1996) and Pandey (2004), that contribute to the debate on the direction of the relationship between firm value and capital structure, but the main issues of the debate have not been resolved.

The paper is arranged in five sections. Following the Introduction is the literature review (Section 2), Section 3 describes data collection, analysis techniques, and empirical analysis, and Section 4 contains the discussion of the results and the conclusion of the study.

\section{Literature Review}

Modigliani and Miller (1958) proposed the popular M\&M theory, which forms the basis of modern thinking in capital structure. The theory has two aspects, cited as propositions I and II. The first proposition states that in a perfect market the value of a firm is not affected by how that firm is financed. This means that firms are indifferent among all possible levels of capital structure. Proposition II deals with the overall weighted average cost of capital as a basis to determine the value of the firm. The central point of this proposition is that an increase or decrease of a component of capital structure (e.g., debt) does not determine the overall weighted average cost of capital. This is because such an increase or decrease is likely to be neutralized by an increase or decrease in the cost of another component, such as equity, thereby pushing the overall weighted average cost of capital to a point of no effect. Therefore, the weighted average cost of capital is likely to be constant at all levels of capital structure, ultimately having no effect on firm value. This presupposes a linear relationship between the cost of equity and the debt-to-equity ratio.

However, a traditional view emerged that maintains that a firm can maximize its value through the judicious use of leverage, as reviewed by Modigliani and Miller (1963). This development is credited to the fact that the initial view of the two popular economists did not consider circumstances in the real world characterized by a number of factors, among which are the following:

1. There are numerous cost elements associated with funding a business.

2. Shareholders face a number of limitations in terms of access to information due to asymmetric forces.

3. Businesses are prone to various types of risk which are determined by the different circumstances under which they operate, among others.

4. Other than the physical costs noted above, economic transactions also have lemon costs that have the tendency to affect the value of a firm.

5. Investors are highly rational and therefore cannot behave the same way under different business conditions.

In recognition of the above factors and the consistent and intense argument on the irrelevance of the M\&M initial propositions, several alternative theories have emerged, demonstrating in various ways how the relationship between capital structure and firm value exists. Prominent among them are the trade-off theory, the pecking order theory, the agency theory and the market timing hypothesis, all of which provide an explanation for the relevance of capital structure. According to Pandey (2005), the trade-off theory provides the nexus which lies on the effect on profits emanating from corporate tax under debt financing, suggesting that the incidence of tax is avoided because interest charges precede tax computations. Apparently, the cost of capital decreases as the proportion of debt increases, which means that managers ordinarily prefer a no equity situation for the firm. But this is limited to the point where bankruptcy costs exceed the benefits derived from the use of debt. Thus, the preference for applying debt is seen from the tax benefit that a company enjoys, which becomes apparent as the cost of capital decreases for an increased use of debt due to tax savings. This could continue up to the point at which bankruptcy costs set in and the marginal benefit of further increases in debt declines with increases in debt as the marginal cost of bankruptcy increases. At this point, a trade off emerges that optimizes the overall value of a firm, which becomes a suitable benchmark for choosing how much debt and equity the company desires. We can also express the effect that tax shields and bankruptcy costs could have on the value of a firm with leverage as follows:

$$
\mathrm{VL}=\mathrm{D}+\mathrm{E}=\mathrm{VU}+\mathrm{PV}(\text { tax shields })-\mathrm{PV} \text { (bankruptcy cost })
$$


where VL is market value of a levered firm, VU is the market value of an unlevered firm, and the present tax shield values and bankruptcy costs are both denoted as PV.

Devereux, Maffini, and Xing (2018) found evidence of the effect of corporate tax on leverage, suggesting a positive relationship between capital structure and firm value. The study confirms that leverage responds positively to decreases in corporate tax.

A cross sectional study by Antwi, Mills, and Zhao (2012) examined the impact of capital structure on firm value in Ghana. They conducted a regression analysis utilizing secondary data from all 34 companies quoted on the Ghana Stock Exchange (GSE) for the year ending December 31, 2010. Using the ordinary least squares (OLS) method of estimation, the study proved that equity capital has a lesser effect than long-term debt in the positive influence they both have on firm value. This result reveals that in an emerging economy such as Ghana, equity capital as a component of capital structure is relevant to the value of a firm, but long-term debt was found to be the major determinant of a firm's value. To this end, corporate managers in Ghana are advised to employ more long-term debt than equity capital to finance their operations.

The studies by Miller (1977) and Myers (1984) highlighted some issues on the incidence of tax upon which Modigliani and Miller (1963) built their argument to support leverage. The cost of corporate and personal taxes borne by shareholders are likely to offset the tax shields because both capital gains and dividends attract taxes, which the companies that previously avoided income tax would now be subjected to bear. This will undermine the extensive application of the trade-off theory because such shields justify the use of debt.

Danis, Rettl, and Whited (2014) revisited the well-established puzzle that leverage is negatively correlated with measures of profitability. In contrast, at times when firms are close to their optimal level of leverage, the cross-sectional correlation between profitability and leverage is positive. At other times, it is negative. These results are consistent with the dynamic trade-off models by Miller (1977). They confirm that the results are not driven by factors such as investment opportunities, market timing strategies, payouts, or reversion of leverage policies.

Titman and Wessels (1988) viewed Scott's model on capital structure and observed that firms with sufficient assets to secure debts are likely to have more debt in their capital structure. But then debt increases have the tendency to cause increases in the value of equity subject to better corporate governance and management proficiency in the effective utilization of such debts. In their findings, firms with low debt ratios are not likely to have high distress costs, and under the tax shield, the government subsidizes the cost of debt.

Cheng, Liu, and Chien (2010) stated that a triple threshold effect exists between leverage and firm value, signifying a correlation, but they identified a definite level beyond which a further increase in debt financing no longer improves firm value. This empirically supports the trade-off theory, providing a basis for tax shields to continuously knock off debt financing costs until a point where increasing agency costs and distress/bankruptcy costs begin to emerge and grow to cover the shields.

In Nigeria, Toby (2010) used earnings per share (EPS), dividends per share (DPS), asset growth, turnover, net profit and shareholders' funds as proxies for corporate performance to study the effects that financial, operating, and even combined leverage could have on them. But the results show that only turnover and profitability have a statistically significant inverse correlation with leverage.

Lawal (2014) examined the effects of both equity and debt on the market value of Nigerian banks using the OLS method. The study is based on panel data consisting of 15 cross-sectional units (quoted commercial banks) covering the period from 2007 to 2012. The results provide evidence that firm value is significantly related to both equity and debt in a linear fashion. This indicates that Nigerian banks can effectively utilize debt. These studies bring to bear the reality of the imperfections inherent in the real world, which are information asymmetry, bankruptcy costs, agency costs, and the gains derivable from leverage induced by tax relief.

\section{Data Empirical Results}

3.1. Data and Sample

According to Brooks (2008), a panel dataset consists of both time series and cross-sectional elements. It is a kind of longitudinal data consisting of repeated observations on variables for large numbers with crosssections in stacked form, such as individuals, organizations, industries or countries, while the time series observations can be hourly, daily, weekly, monthly, quarterly, and yearly. If $N$ represents the cross-sectional units and $T$ represents the time series observations, then there is a total of $(N \mathrm{x} T)$ observations for the panel data. With the combination of both time series and cross-sectional dimensions, it provides a rich dataset sufficient for asymptotic benefits and a better framework for modelling cross-sectional heterogeneity than the cross-sectional data type.

Panel data is balanced if all the cross-sectional units have equal date observations and there are no missing date observations. On the contrary, an unbalanced panel dataset contains missing date observations. In other words, an unbalanced panel data contains unequal date observations for the cross-sectional units.

A panel dataset is short if it consists of few date observations and large cross-sectional units. Thus, for short panel data, the cross-sectional dimension, $N$, is relatively large, while the time series dimension, $T$, is 
relatively small (i.e., $N>T$ ). On the contrary, when small cross-sectional units, $N$, are observed over a long time, $T$, we say that the panel data is long (i.e., $N<T$ ). The choice between long and short panel data depends on data availability and the assumption made regarding cross-sectional heterogeneity. If the date observations on each cross-sectional unit are richly available and the cross-sectional heterogeneity or individual effects vary with time, then long panel data is appropriate. On the other hand, short panel data may be used if the date observations are in limited supply and the individual effects are time-invariant.

All the companies listed on the Nigeria Stock Exchange form the population of this study. As of the 2016 financial year, there were a total of 170 companies or securities (NSE, 2016), which were categorized into 12 industries or sectors, namely Agriculture, Construction/Real Estate, Consumer Goods, Financial Services, Health Care, Industrial Goods, Information and Communication Technology (ICT), Natural Resources, Oil and Gas, Services, Utilities, and Conglomerates.

A total of 60 companies are used in this study, which represents about $36 \%$ of the population. A nonprobability sampling technique was used to select the sample. Specifically, the 60 companies were purposively selected from the 12 industries or sectors (at least five from each industry) that constitute the study population. The period covered is the 27 years from 1990 to 2016. Thus, the sample consists of 1,620 $(N \mathrm{x} T)$ panel data observations. The other criteria used to select the companies are as follows:

1. The companies must have been listed on the Nigeria Stock Exchange for the years within this period.

2. The companies must have consistently published their reports and accounts for the entire 27-year period (1990 to 2016).

3. The companies were not acquired in any form within this defined study period.

4. The companies (especially banks) have no issues regarding bad debt or non-performing loans.

It is our view that observations for 60 companies over a 27 -year period fit the aforementioned definition of panel data. It is also our view that a sample size of 1,620 is sufficient to obtain consistent, unbiased and reliable results that will truly represent the population.

Yearly time series observations for the 60 selected companies are used. The variables are market value per share, long-term debt, short-term debt, corporate tax, non-current assets, total assets, and shareholders' equity. The data on the study variables were obtained through secondary sources, specifically from annual reports and accounts of the selected companies for different years submitted to the Nigeria Stock Exchange, obtained from the Port Harcourt branch.

\subsection{Methods of Data Analysis}

There are three different models and/or methods of data analysis within the panel data framework pooled regression, fixed effects and random effects.

The first stage of the data analysis in the panel data framework is to run a pooled least squares regression, which involves pooling all the data together regardless of heterogeneity or cross-sectional differences (Brooks, 2008). One alternative to the pooled least squares approach that accommodates the heterogeneity in the panel data is the fixed effects approach, which is specified as follows:

$$
Y_{i t}=\left(\alpha+\gamma_{i}\right)+X_{i t} \beta+\epsilon_{i t}
$$

In comparing the fixed effects model with the pooled model, the latent parameter $\gamma_{i}$ accounts for the cross-sectional heterogeneity that affects $Y_{\text {it }}$ but does not vary with time. The cross-sectional heterogeneity may be in the form of differences in managerial styles and cultures of different companies or industries where firms operate and compete, etc. (Brooks, 2008). Thus, the fixed effects approach accommodates the crosssectional heterogeneity or differences which are not directly observable by including the latent parameter $\gamma_{i}$ in the model.

The second alternative to the pooled regression model, which also accommodates cross-sectional heterogeneity in panel data, is the random effects model.

\subsection{Model Specification}

The functional specification of the relationship between corporate tax and the market value of firms is expressed in the following model:

$$
\text { MVS }=f(T A X, T A N G)
$$

Where:

MVS = Firm market value per share or share price

$T A X=$ Corporate tax

The econometric parameterization of the above model is given as:

$$
\text { MVS }_{i t}=\gamma_{0}+\gamma_{1} T A X_{i t}+\gamma_{2} T A N G_{i t}+v_{i}+\mu_{i t}
$$

Where $\gamma_{0}$ is the regression constant, $v_{i}$ represents the unobserved firm-specific factors, $\mu_{i t}$ the disturbance terms, and the parameter $\gamma_{1}$ is the regression slope, which is also cross-sectionally constant. If the latent variables are found to be insignificant, then the model is a pooled regression specification. On the other hand, if these latent factors are significant and correlate with the independent variables, then our model is a fixed 
effects specification. If there is no such correlation, then our model is a random effects specification and can be estimated using the generalized least squares (GLS) technique. There is, therefore, good reason to consider the two hypotheses associated with the conventional panel data methodology because the unobserved firm-specific variables are jointly not different from zero, and the unobserved firm-specific factors are uncorrelated with the observed variables. Rejection of the first hypothesis would imply that the unobserved firm-specific effects are important determinants of the market value of firms listed on the Nigeria Stock Exchange and ignoring these important variables would lead to heterogeneity bias. Thus, the pooled least squares model is not a plausible description of our panel data.

In addition to the usual t-test and F-test, which are used to test the significance of the individual betas and the feedback causality between firms' market value and corporate tax, we adopt other hypothesis testing methods under the panel data framework, such as the likelihood ratio (LR) test and the Hausman specification test. These tests are also used to choose the best panel data model for our sample and data.

Table 1 shows the estimation results and the goodness of fit statistics based on the three panel data models (pooled regression, fixed effects and random effects). The model expresses a firm's market value (MVS) as a function of corporate tax (TAX).

Table 1. Panel estimation results.

\begin{tabular}{l|c|c|c}
\hline Variable & Pooled estimate & Fixed effects estimate & Random effects estimate \\
\hline Constant & $0.5648(0.0000)$ & $0.9582(0.0000)$ & $0.9056(0.0000)$ \\
\hline LT $A X$ & $0.3027(0.0000)$ & $0.1965(0.0000)$ & $0.2054(0.0000)$ \\
\hline LT $A N G$ & $-0.0384(0.0560)$ & $-0.0312(0.0647)$ & $-0.0308(0.0663)$ \\
\hline R-squared & 0.2098 & 0.6219 & 0.0979 \\
\hline Adj. R-squared & 0.2087 & 0.6050 & 0.0966 \\
\hline F-statistic & $185.2407(0.0000)$ & $36.6632(0.0000)$ & $75.7492(0.0000)$ \\
\hline Durbin-Watson $(\mathrm{DW})$ & 0.3410 & 0.6524 & 0.6263 \\
\hline
\end{tabular}

Note: The $p$-values are in parentheses.

From Table 1, we can see that the estimates of the three models are broadly similar, with the coefficient of LTAX (beta $>0$, p-value $=0.0000$ ) consistently showing a positive sign and a very low probability. Thus, firm market value is a positive and highly significant function of corporate tax.

For all methods, the F-statistic is quite high with zero probability (p-value $=0.0000$ ), suggesting that the joint effect of tax and tangibility on firm market value is highly significant. However, the fixed effects model has a much higher adjusted R-squared (0.6050) than both the random effects (0.0966) and the pooled regression (0.2087) models, suggesting that the fixed effects method fits our panel data much better than its rivals. Thus, the proportion of the total variation in a firm's market value that is due to corporate tax is approximately $60 \%$ for the fixed effects model, $9 \%$ for the random effects model, and $20 \%$ for the pooled regression model. Similarly, the fixed effects model has the highest Durbin-Watson value (DW $=0.6524$ ) compared to the random effects model $(\mathrm{DW}=0.6263)$ and the pooled regression model $(\mathrm{DW}=0.3410)$. Therefore, the fixed effects approach seems to be the best fitting model for the relationship.

From the table, the p-value corresponding to LTAX (log of corporate tax) for the random effects model is 0.0000 , which is substantially lower than 0.05 . Therefore, we strongly reject the null hypothesis and conclude that there is a highly significant relationship between corporate tax and the market value of quoted firms in Nigeria.

Table 2 shows the formal specification test results for the relationship. The likelihood ratio and Hausman tests are also shown. For the likelihood ratio test, which formally compares the pooled regression model with the fixed effects model, the null hypothesis is that the firm-specific factors are not significant explanatory variables in the model. A rejection of this test assumption would imply that the fixed effects estimates are more reliable than those of the pooled regression model. For the Hausman specification test, the comparison is between the fixed effects and the random effects models under the null hypothesis that firm-specific factors are uncorrelated with corporate tax.

Table 2. Model selection test results.

\begin{tabular}{l|c|c}
\hline Test & Chi-square statistic & $\boldsymbol{p}$-value \\
\hline Likelihood ratio test & 1030.694 & 0.0000 \\
\hline Hausman test & 4.4058 & 0.1105 \\
\hline
\end{tabular}

From the table, we can see that while the likelihood ratio test is highly significant (p-value $=00000)$, the Hausman specification test is insignificant, even at the $10 \%$ level ( $p$-value $=0.1105)$. Thus, we strongly reject the pooled regression estimates in favor of the fixed effects estimates and conclude that the unobserved firm- 
specific variables are significant in our empirical model. Further, we do not reject the null hypothesis of the random effects model, so the firm-specific effects are uncorrelated with corporate tax.

Table 3 shows the pairwise Granger causality test results for corporate tax and firm market value. The causality from corporate tax to firm market value is tested under the null hypothesis that LTAX does not Granger cause LMVS. A rejection of this null hypothesis would imply evidence of a unidirectional causality from corporate tax to firm market value. On the other hand, the reverse causality is tested under the null that LMVS does not Granger-cause LTAX. A rejection of this null would imply evidence of a unidirectional causality from firm market value to corporate tax. However, if both null hypotheses are rejected, then there is evidence of a feedback causality between firm market value and corporate tax. On the contrary, if both hypotheses are not rejected, then there is no causality between the two variables. Again, we include only one lag of each variable in each test equation.

Table 3. Causality test between firm market value and corporate tax.

\begin{tabular}{l|c|c}
\hline Null hypothesis & F-statistic & Probability \\
\hline LTAX does not granger-cause LMVS & 20.7901 & $6 . \mathrm{E}-06$ \\
\hline LMVS does not granger-cause LTAX & 16.4048 & $5 . \mathrm{E}-05$ \\
\hline
\end{tabular}

From Table 3, we can see that the associated probability of the F-statistic (p-value $<0.05)$ is very low in both cases, suggesting that the test is highly significant. Therefore, both null hypotheses are strongly rejected, and there is a bidirectional or feedback causal link between corporate tax and market value of shares quoted on the Nigeria Stock Exchange.

\section{Discussion and Conclusion}

The relationship between corporate tax and market value of quoted firms in Nigeria is found to be significant and bidirectional. Based on the empirical analysis, corporate income tax has a linear relationship with the value of a firm and at the same time there is a feedback effect running from the value of a firm to capital structure through corporate tax. So, with any change in the amount of corporate income tax that a firm records, there is a tendency for it to cause about $21 \%$ of the change in the market value of shares of these companies, as explained by the coefficient of determination. Invariably, changes in the market value of shares would cause a reverse effect in the amount of corporate tax the companies are required to post to their profit and loss statements, explained by an F-statistic of 16.4048. These findings are robust with few empirical works supporting various aspects.

First, recent work by Devereux et al. (2018) found evidence that corporate tax has a positive effect on the value of firms through leverage. This also confirms the revised work of Modigliani and Miller (1963) and the fact that leverage is enhanced by the amount of corporate tax through the shields provided from the deductions that firms are expected to make in their income statements.

Second, De Jong (2002) established a bidirectional relationship between leverage and firm value with evidence that long-term debt significantly affects firm value, which, in turn, influences leverage through corporate tax.

It is pertinent to mention that firm value is expressed in terms of both the value of levered firms and unlevered firms, with the former defined as the sum of total debt and equity at any given time. However, in estimating the value of a levered firm, it is appropriate to derive an econometric expression that captures a relationship with an unlevered firm which is added to a value derived from the present value of the amount of corporate tax deducted by the present value of any associated cost from possible bankruptcy that the firm may experience.

It is necessary to explain the concept of a tax shield, which is the factor that brings about an advantage in the use of leverage, as established in the revised work of Modigliani and Miller (1963). We can easily express the value of that shield provided by corporate tax in terms of both interest on debt and the prevailing tax code in an economy as well as the proceeds likely to be generated from the use of the funds borrowed. Then the amount of shield a company can enjoy is obtained from the product of interest and the tax rate denominated by the amount of proceeds expected from the use of the borrowed funds.

From Miller (1977) and Myers (1984), there are limitations on corporate tax as a variable to determine firm value owing to the existence of personal income tax, capital gains tax and other forms of shield, such as depreciation and investment credits from financial leases which would reduce the taxable profit. However, they advocate the use of earnings before interest, depreciation and taxes (EBIDT) as proxies to establish the actual effect that corporate tax could have on firm value. This explanation does not limit the findings on the effect of corporate tax on the value of the quoted firms and vice versa. Firstly, the other forms of shield that reduce taxable profits, and by extension enhance the distributable profit or increase the value of firms, are not alternatives. Secondly, all the factors that contribute to tax shields are independently determined by the prevailing tax rate on one hand and the volume of each item on the other hand. For instance, a tax rate of $40 \%$ would provide a different amount of shield from loans, investment credits and depreciation according to the 
volume of each. In our view, rather than seeing them as competing factors, they are various ways of providing shields to enhance the value of firms.

Titman and Wessels (1988) found empirical evidence that these non-debt tax shields have a substantial effect on the value of firms. The question then is, what are the indicators of the non-debt tax shields and how do they enhance the value of firms to be able to relate their effects to the findings of this study?

We can identify a few channels through which non-debt shields can affect the value of firms other than the variables tested in this study. Firstly, the ratio of investment tax credits to total assets clearly explains the extent to which provisions for tax exemptions are made from the amount of investments a company makes in assets whether by internal or external funds. A higher ratio signifies a higher non-debt shield, explaining that much of the increase in firm value can be traced to investments in assets that are derived through leases and other related means of financing corporate growth.

Another factor that indicates non-debt shield is operating income, which is derived from gross profit before deducting depreciation, interest charges and tax. Its main determinants are operating costs and gross profit further determined by the extent to which managers are able to cut the cost of raw materials. Operating income moves in the same direction as the market value of company shares.

Interest payments take the form of investment credits and are both allowances that reduce the taxable income and the amount of tax that a firm is required to post. Judging from theoretical knowledge, the more allowances created by these credits, the less the amount of tax payable, thereby establishing an inverse relationship between all forms of investment credits, including interest payments and corporate income tax. Given the positive effect that tax has on the value of firms, there is a tendency for these allowances to also affect the value of firms negatively.

Furthermore, both long-term debt and leases can provide double effects on taxable income through the shields if the borrowed funds are used to acquire fixed assets. This is due to the fact that the interest payments are exempt from tax, and the assets also provide depreciation allowances, with both bringing about shields in different ways.

Most profoundly, this study proves that corporate tax has a strong explanatory power on the market value of shares quoted on the Nigeria Stock Exchange, with a feedback response justifying a bidirectional relationship between the two variables.

The foregoing proves that our findings show some level of consistency with previous works within the subject matter and in some cases expands the findings of earlier works, thereby becoming more robust. This is made possible by the considerably wider scope and the fact that the study took account of all stages of the Nigerian economy with its strategic emerging market posture. For instance, like the study by Pandey (2001), which covered the periods of downturn and upturn in the Malaysian economy, ours took its scope from 1990 when the Nigerian Capital Market was in its infancy and extended it up to 2017, capturing recent developments.

Corporate tax proved to be a key determinant of decision making in the use of debt by the companies studied. This is evident from the bidirectional relationship established between tax and the value of the firms, which is highly significant at both levels. It therefore serves as a basis to extend the trade-off theory from the initial position as posited by Modigliani and Miller (1963). However, the tax data obtained from the annual reports pose a threat to the reliability of this result because Devereux et al. (2018) found evidence that tax figures from published financial statements in the United Kingdom have a weaker explanatory power.

In this study, we have examined the relationship between the tax effects of capital structure and the market value of quoted companies with evidence from the Nigerian capital market using data from 60 quoted firms across all the sectors of the economy. In view of the need to choose a research strategy that naturally supports the main objectives, we adopted the panel data methodology with adequate considerations for time series and industry analysis effects. The effect of a tax shield on the value of Nigerian quoted companies is highly significant and therefore should be considered by managers of the firms and policy makers to strike a balance between the gains to business owners and the losses of revenue to the government. Corporate managers in Nigeria should also consider other means of shields, such as depreciation and investment credits from leases, in their decisions to maximize the wealth of shareholders because the absolute reliance on tax relief as a means of gaining an advantage in debt financing does not rule out the existence of other types of shields to obtain higher profitability.

\section{References}

Akeem, L. B. (2014). Effect of capital structure on firm performance. Journal of Finance and Investment, 3(4), 39-57.

Antwi, S., Mills, E. F. E. A., \& Zhao, X. (2012). Capital structure and firm value: Empirical evidence from Ghana. International Journal of Business and Social Science, 3(22), 103-110.

Baker, M., \& Wurgler, J. (2002). Market timing and capital structure. The Journal of Finance, 57(1), 1-32.

Barclay, M. J., \& Smith, C. W. (1996). On financial architecture: Leverage, maturity, and priority. Journal of Applied Corporate Finance, 8(4), 4-17. https://doi.org/10.1111/j.1745-6622.1995.tb00679.x

Baskin, J. (1989). An empirical investigation of the pecking order hypothesis. Journal of Financial Management, 1(1), $26-35$.

Bradley, M., Jarrell, G. A., \& Kim, E. H. (1984). On the existence of an optimal capital structure: Theory and evidence. The Journal of Finance, 39(3), 857-878. https://doi.org/10.1111/j.1540-6261.1984.tb03680.x 
Brooks, C. (2008). Basic econometrics for finance. New York: Cambridge University Press.

Campbell, D. E., \& Kelly, J. S. (1994). Applications of the trade-off theory. American Economic Review, 84(2), 422-426.

Cheng, Y.-S., Liu, Y.-P., \& Chien, C.-Y. (2010). Capital structure and firm value in China: A panel threshold regression analysis. African Journal of Business Management, 4(12), 2500-2507.

Danis, A., Rettl, D. A., \& Whited, T. M. (2014). Refinancing, profitability, and capital structure. Journal of Financial Economics, 114(3), 424-443. https://doi.org/10.1016/j.jfineco.2014.07.010

De Jong, A. (2002). The disciplining role of leverage in Dutch firms. Review of Finance, 6(1), 31-62. https://doi.org/10.1023/a:1015082700388

Devereux, M. P., Maffini, G., \& Xing, J. (2018). Corporate tax incentives and capital structure: New evidence from UK firm-level tax returns. Journal of Banking $\mathcal{E}^{2}$ Finance, 88, 250-266. https:// doi.org/10.1016/j.jbankfin.2017.12.004

Lawal, A. (2014). Capital structure and the value of the firm: Evidence from the Nigerian banking industry. Journal of Accounting and Management, 4(1), $31-41$.

Miller, M. H. (1977). Debt and taxes. Journal of Finance, 32(2), 1-9.

Modigliani, F., \& Miller, M. H. (1958). The cost of capital, corporation finance and the theory of investment. The American Economic Review, 48(3), 261-297.

Modigliani, F., \& Miller, M. H. (1963). Corporate income taxes and the cost of capital: A correction. The American Economic Review, 53(3), 433-443.

Myers, S. C., \& Majluf, N. S. (1984). Corporate financing and investment decisions when firms have information that investors do not have. Journal of Financial Economics, 13(2), 187-221. https://doi.org/10.1016/0304$405 \times(84) 90023-0$

Myers, S. C. (1984). The capital structure puzzle. Journal of Finance, 39(3), 575-592.

NSE. (2016). The Nigerian stock exchange factbook. Lagos: Nigerian Stock Exchange.

Pandey, I. M. (2004). Capital structure, profitability and market structure: Evidence from Malaysia. Asia Pacific Journal of Economics and Business, 8(2), 78-91.

Pandey, I. M. (2005). Financial management. New Delhi: Vikas Publishing House.

Pandey, I. M. (2001). Capital structure and the firm characteristics: Evidence from an emerging market. IIMA Working Paper,2001-10.

Titman, S., \& Wessels, R. (1988). The determinants of capital structure choice. The Journal of Finance, 43(1), 1-19.

Toby, A. J. (2010). Leverage policy, corporate growth and investment performance in Nigerian quoted companies. Journal of Business Studies, $12(1), 30-56$. 